\title{
Potential Antibacterials Compounds of Lactic Acid Bacteria (LAB) from Quail Intestine (Coturnix japonica) in Inhibition Growth of Escherichia coli and Salmonella typhimurium
}

\author{
Pupimadita T. Afdora ${ }^{1 *}$, Tri Ardiyati ${ }^{1}$, Osfar Sjofjan ${ }^{2}$ and Umi Kalsum ${ }^{3}$ \\ ${ }^{1}$ Department of Biology, Faculty of Mathematics and Natural Sciences, Brawijaya University, Malang \\ ${ }^{2}$ Department of Animal Nutrition, Faculty of Animal Husbandry, Brawijaya University, Malang \\ ${ }^{3}$ Husbandry Faculty, Islamic University of Malang..
}

\begin{abstract}
Quail (Coturnix japonica) is a bird that have high protein content, but vulnerable to digestive diseases. The purpose of this research was to determine the ability of antibacterial compounds of LAB from intestinal quail origin in bacterial growth inhibition test. This research used Completely Randomized Design (CRD) with variable concentrations of Cell Free Supernatant (CFS) for 10, 20, 30, 40, 50, and 60\% and bacterial pathogens of the digestive tract of quail (S. typhimurium, E. coli of human origin, and E. coli of bird origin) by using the Minimum inhibitory Concentration (MIC) and Minimal Bactericidal Concentration (MBC). The data obtained were analyzed by Analysis of Variance (ANOVA). The results obtained showed that the bacterium Lactobacillus fermentum and L. salivarius derived from quail intestine can produce antibacterial compounds that could inhibit the growth of Salmonella typhimurium, Eschericbia coli (human), and E. coli (bird). Minimum concentration of the addition of CFS from L. fermentum in inhibiting the growth of tested bacteria was 30\% for S. typhimurium, $30 \%$ for E. coli (human), and $20 \%$ for E. coli (bird). While the addition of CFS minimum concentration of L. salivarius in inhibiting the growth of tested bacteria was $20 \%$ for S. typhimurium, $20 \%$ for E. coli (human), and $10 \%$ for E. coli (bird).
\end{abstract}

Keywords: Antibacterials, Lactic Acid Bacteria (LAB), Escherichia coli, Quail, and Salmonella typhimurium.

\section{Introduction}

Quail (Coturnix japonica) is birds that has high protein content but are vulnerable to gastrointestinal diseases caused by bacterial pathogens. One way the body's defense against bacterial pathogens are to associate with Lactic Acid Bacteria (LAB) to maintain the balance of bacterial gastrointestinal conditions by modifying the gut microflora with the products produced by bacteria such as short-chain fatty acid or lactic acid and antibacterial compounds [1]. Lactic Acid Bacteria (LAB) from the intestine of quail found in previous studies is Lactobacillus salivarius and Lactobacillus fermentum are known to have potential as probiotic bacteria [2]. Characteristics of probiotic bacteria are able to survive the digestive conditions, can colonize, and develop properly in the intestines by means attached to the intestinal

\footnotetext{
*Corresponding address:

Pupimadita Tizar Afdora

Biology Department, Brawijaya University

Jl. Veteran, Malang 65145,

East Java, Indonesia

Email: idnd.yueclue.aika@gmail.com
}

epithelium [1] and be able to produce antibacterial compounds that could inhibit the growth of pathogenic bacteria [3]. Antibacterial compounds produced a mixture of several compounds such as bacteriocin, antibiotic, lactic acid, acetic acid and hydrogen peroxide. Optimal inhibition of pathogenic bacteria such as Eschericbia coli and Salmonella typhimurium, which is one cause of high mortality in poultry, is still not known. Therefore, there should be more research about the ability of Lactobacillus salivarius and Lactobacillus fermentum in the inhibition of bacterial growth of Escherichia coli and Salmonella typhimurium to increase immune power against gastrointestinal diseases.

\section{Method \\ Making Growth Curve}

Making the growth curve starts with a stocktaking as much as $10 \%$ of the inoculums production medium with a density $10^{7}$ cells $/ \mathrm{ml}$ and incubated on a rotary shaker with $120 \mathrm{rpm}$, $37^{\circ} \mathrm{C}$ for 34 hours. Bacterial cell density were observed every one hour in the first four hours and continued every two hours until the 30 hour by measuring OD values $\lambda 412 \mathrm{~nm}$ for MRSB. 
Cell density of bacteria/ml can be calculated by entering the $\mathrm{OD}$ values obtained on standard curve equation of bacterial cell density.

\section{Detection of Compounds Produced by LAB Antibacterial Free Cell Preparation supernatant (CFS)}

The initial steps was to grow in $100 \mathrm{ml}$ of LAB isolates MRSB media to late logarithmic phase and centrifuged at $10000 \mathrm{rpm}$ for 10 minutes at $4^{\circ} \mathrm{C}$. Supernatant obtained by a Free Cell supernatant (CFS) to be used for detection and treatment of bacterial tests with test antagonist. Before being used for the treatment of CFS first filtrated using $0.22 \mu \mathrm{m}$ pore membrane filter [2].

\section{Ability Test Compounds Antibacterial by agar diffusion method}

Test the ability of antibacterial compounds produced by BAL analysis was conducted using antagonist. The initial steps used are NA inoculated with $10^{7}$ cells $/ \mathrm{ml}$, then made a hole in the media by using a six-mm diameter cork borer and added $50 \mu \mathrm{l} \mathrm{CFS}$, incubated at $37^{\circ} \mathrm{C}$ for 24 hours. Controls used were sterile MRSB media is added to the wells. Calculations wide clear zone can be done with the formula 1 .

Wide zone $=$

diameter of clear zone-diameter hole

2

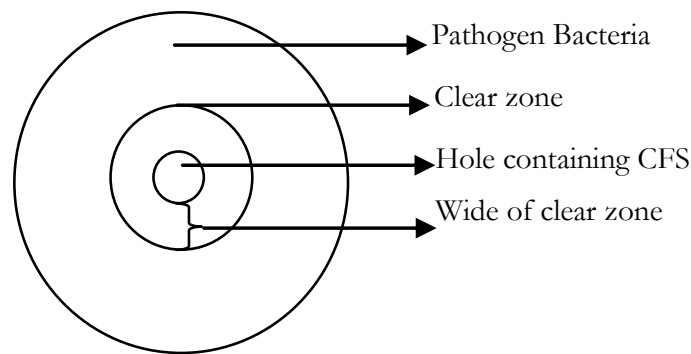

Figure 1 Diagram antibacterial capability test method in bacterial growth inhibition test

\section{Detection of Type Compounds Produced Antibacterial}

Antibacterial compounds produced by LAB include lactic acid, hydrogen peroxide and bacteriocin. Way used to determine which type of antibacterial generated is by changing the $\mathrm{pH}$ of the CFS to be 7 .

\section{Antagonism Test with Minimum inhibitory Concentration (MIC) and Minimum Bactericidal Concentration (MBC)}

The initial steps are inoculated $0.1 \mathrm{ml}$ of test bacterial suspension with cell density of $10^{6}$ cells $/ \mathrm{ml}$ in Luria Bertani medium (LB) supplemented with various concentrations of CFS at $10 \%, 20 \%, 30 \%, 40 \%, 50 \%$ and $60 \%$ of final volume of solution. The next step, OD values measured with a wavelength of $412 \mathrm{~nm}$ to obtain OD value of beginning. Further testing of bacterial suspension and incubated for 24 hours CFS at $37^{\circ} \mathrm{C}$. After incubation, done taking as many as three $\mathrm{ml}$ for OD measurement as final OD values to determine the level of inhibition of growth of pathogenic bacteria by antibacterial obtained and compared with the initial OD for MIC results. While to obtain the value of MBC, was counted by using Total Plate Count (TPC).

\section{Study Design and Data Analysis}

This research using Completely Randomized Design (CRD) with variable concentrations of three replicates CFS. The data obtained were analyzed by analysis of variance (ANOVA) using $95 \%$ confidence interval followed by Duncan test [4].

\section{Results and Discussion \\ Growth Curve of Lactic Acid Bacteria.}

Both of Lactic Acid Bacteria (LAB), L. fermentum and $L$. salivarius have different growth patterns (Figure 2). The growth rate of $L$. fermentum at the logarithmic phase of 0.13 generations/hour by hour or 5.24 generation time (5 hours 14 minutes) and growth rate of $L$. salivarius in the logarithmic phase of 0.32 generations/hour by hour or 2.15 generation time (two hours nine minutes). These results suggest that the rate of growth of $L$. salivarius faster than $L$. fermentum. Bacterial growth is generally influenced by several factors such as temperature, $\mathrm{pH}$, humidity, carbon, nitrogen, minerals (macro and micro nutrients), and vitamins [9]. In the lag phase, bacteria have acclimatization in new environmental conditions $(\mathrm{pH}$, temperature, nutisi, etc.) and no significant increase in cell density with time [10]. On the growth curve of $L$. salivarius showed a long lag phase because the cells changes cell mass and increased intracellular substance so that the cell ready to divide. 


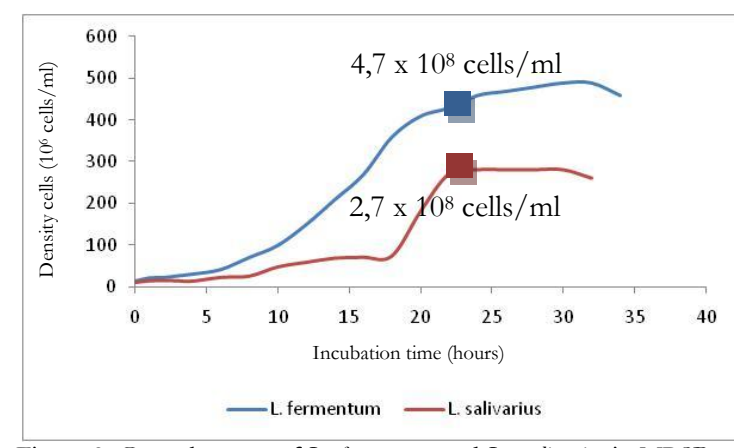

Figure 2. Growth curve of L. fermentum and L. salivarius in MRSB

Increased cell density significantly occurred in log phase. This happens because in this phase of cell division is more active with a minimum generation time is constant. This phase is depicted as a line, which increases. Rapid growth rate or the relatively short generation time is achieved by utilizing nutrients as the optimal energy source. Late log phase in isolates of $L$. fermentum and L. salivarius occurred on 24-hour incubation period with successive cell density was $4.7 \times 10^{8}$ cells $/ \mathrm{ml}$ and $2.7 \times 10^{8}$ cells $/ \mathrm{ml}$. Secondary metabolites, including compounds such as lactic acid and bacteriocin produced during logarithmic phase, so in late logarithmic phase of antibacterial compounds found in the maximum amount [10].

\section{Detection Capability and Type Compounds Antibacterial LAB (CFS) In Bacterial Growth Inhibition Test.}

Treatment with test bacteria S. typhimurium, an average width of clear zone produced by CFS $L$. fermentum amounted to $9.04 \mathrm{~mm}^{2}$ and $L$. salivarius amounted to $78.07 \mathrm{~mm}^{2}$. Then the test bacteria E. coli of human origin, an average width of clear zone produced by CFS $L$. fermentum amounted to $22.8 \mathrm{~mm}^{2}$ and $L$. salivarius of $136.64 \mathrm{~mm}^{2}$. Subsequently the bacteria E. coli origin of bird, an average width of clear zone produced by CFS L. fermentum amounted to $22.11 \mathrm{~mm}^{2}$ and L. salivarius amounted to 77.10 $\mathrm{mm}^{2}$. Based on the broad

clear zone is produced, it is known that the antibacterial compound produced by L. salivarius has a higher ability in inhibiting bacterial growth than the test of antibacterial compounds produced by L. fermentum. Antibacterial compounds produced compounds probably derived from lactic acid because it can alter the initial $\mathrm{pH}$ value from 6 to 4.1 for L. fermentum and to 4.3 for L. salivarius.
Test Results of detection of antibacterial compounds contained in the CFS L. fermentum and $L$. salivarium formation on all the tested bacteria (Figure 3). Suggesting the formation of clear zone caused by the low pH of the CFS, which means that the produced acid compounds that can lower the $\mathrm{pH}$ of growth media. According Skrinova et al [5] and Presser et al [6], lactic acid concentration can affect the growth of some pathogenic bacteria such as E. coli, Salmonella sp., and Clostridium perfringens. Growth inhibition caused by the total concentration of lactic acid and the amount of hydrogen ions $(\mathrm{pH})$ which is an important factor for the occurrence of growth retardation. Mechanism involved is the lactic acid that has not been able to release ions into the cell membrane of bacteria that cause acidic conditions in the cytoplasm and disrupt the membrane potential. Furthermore, the underlying excess of protons exit the membrane that uses energy from ATP resulting run out of energy and cause cell death.

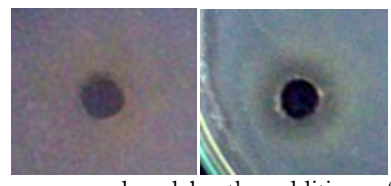

Figure 3. Clear zone produced by the addition of $100 \%$ of CFS against bacteria test

Based on these capabilities, allegedly $L$. fermentum and L. salivarius from quail intestine can be used as a probiotic because it meets one of the requirements that probiotics can produce antibacterial compounds. Another Term as probiotic bacteria have properties that are tolerant of various bile salt concentration and $\mathrm{pH}$ of the digestive tract and be able to attach (adhesion) with the surface of intestinal epithelial cell [8]. Isolates of L. salivarius and $L$. fermentum able to survive in the gut $\mathrm{pH}$ by the addition of $0.3 \%$ bile salts and $1 \%[8]$.

\section{CFS Ability Test In Bacterial Growth Inhibition}

\section{CFS from L. fermentum}

Test the ability of inhibition of multiple variations of the concentration of CFS $L$. fermentum against bacteria growth test method Minimum inhibitory Concentration (MIC) by showing that increasing the minimum concentration that can inhibit bacterial growth of $S$. typhimurium and E. coli of human origin is $30 \%$ while for $\mathrm{E}$. coli origin of bird requires a 
minimum concentration is $20 \%$. TPC calculations results show that CFS is able to inhibit the growth of S. typhimurium $100 \%$ at a concentration of $50 \%$ and $E$. coli origin of livestock at a concentration of $60 \%$. While the tested bacteria $E$. coli of human origin, the concentration of $60 \%$ of CFS were added still can not kill all the bacteria tested in it. However, when compared with test results CFS detection capability, with the addition of CFS with $100 \%$ concentration can inhibit the growth of E. coli of human origin as shown by the formation of clear zone around the shaft, the addition of CFS. So the alleged ability of CFS with $60 \%$ concentration is still less than $100 \%$ to inhibit growth or kill all E. coli of human origin are treated.

\section{CFS from L. salivarius}

Test the ability of inhibition of multiple variations of the concentration of CFS $L$. salivarius on the growth of test bacteria with MIC method known to the minimum concentration that can inhibit bacterial growth of $S$. typhimurium and E. coli of human origin is $20 \%$ while for $E$. coli of bird origin minimum concentration required is $10 \%$, TPC calculation results show that the antibacterial compound produced by $L$. salivarius inhibited 100\% growth of all bacteria tested with the addition of CFS minimum concentration of $40 \%$ for S. typhimurium, 50\% for $E$ coli (human), and $40 \%$ for $E$. coli (bird). From these results, it is known that CFS produced by L. salivarius has a higher inhibitory ability than that CFS produced by L. fermentum are shown with the addition of a smaller concentration of CFS but have better results in the inhibition of bacterial growth test.

\section{Conclusion}

Bacteria L. fermentum and L. salivarius derived from quail intestine can produce antibacterial compounds that could inhibit the growth of test bacteria namely S. typhimurium, E. coli (human), and E. coli (bird). Minimum concentration of the addition of CFS from L. fermentum in inhibiting the growth of tested bacteria was $30 \%$ for $S$. typhimurium, 30\% for E. coli (human), and 20\% for E. coli (bird). While the addition of CFS minimum concentration of $L$. salivarius in inhibiting the growth of tested bacteria was $20 \%$ for S. typhimurium, 20\% to E. coli (human), and $10 \%$ for E. coli (bird).

\section{References}

[1] Fuller R, Probiotics 2 Application and Practical Aspect. Chapman and Hall. London, 1997.

[2] Collins JK, O'sullivan GC, Thornton GM, O'sullivan, MM, Geraldin E. Probiotic strains from Lactobacillus salivarius and antimicrobial agents obtained therefrom. United States Patent 7186545. 2007.

[3] Natalia L, Priadi A. Sifat Lactobacilli Yang Diisolasi Dari Usus Ayam Sebagai Probiotik. Seminar Nasional Teknologi Peternakan dan Veteriner. 2006.

[4] Salmon S A, Watts JL, Aarestrup FM, Pankey JW, Yancey RJ Jr., Minimum Inhibitory Concentrations for Selected Antimicrobial Agents Against Organisms Isolated from the Mammary Glands of Dairy Heifers in New Zealand and Denmark. Journal of Dairy Science. 1998; 81 (2): 570-578.

[5] Skrinova E, Marouenek M, Benda V, Brezina P. Susceptibility of Escherichia coli, Salmonella sp. and Clostridium perfringens to Organic Acid and Monilaurin. Veterinary Medicina. 2006;51 (3):81-88.

[6] Presser D, Ratkowsky A, Ross T. Modelling The Growth Rate of Escherichia coli as a Function of $\mathrm{pH}$ and Lactic Acid Concentration. Applied and Environmental Microbiology. 2007; 63 (6): 2344-2360.

[7] Jacobsen CN, Nielsen VR, Hayford AE, Moller PL, Michaelsen KF, Paerregaard A, Sandstrom B, Tvede M, Jacobsen M. Screening of Probiotic Activities of Fory-Seven Strains Lactobacillus spp. by In Vitro Techniques and Evaluation of The Colonization Ability of Five Selected Strains in Human. App and Env. Microbiology. J. 1999; 65 (11): 4949-4956.

[8] Kartikasari, N., Identifikasi Bakteri Asam Laktat (Bal) Dari Usus Burung Puyuh (Coturnix Japonica) Serta Potensinya Sebagai Probiotik. S.Si Thesis. Brawijaya University, Biology Department; 2010.

[9] Sjofjan, O. Isolasi dan Identifikasi Mikroflora Usus Ayam Petelur Sebagai Sumber Probiotik. Research paper, Brawijaya University. 2001.

[10] Madigan MT, Martinko JM, Parker J. Brock Biology of Microorganism. Pearson Education, Inc. Southern Illinois. 2003. 